\title{
Capital Structure Determinants: A Cross-Country Analysis
}

\author{
Nader Alber ${ }^{1} \&$ Iman S. Youssef ${ }^{2}$ \\ ${ }^{1}$ Professor of Finance, Ain Shams University, Cairo, Egypt \\ ${ }^{2}$ Assistant Professor, New Giza University, Cairo, Egypt \\ Correspondence: Nader Alber, Ain Shams University, Cairo, Egypt.
}

Received: March 12, 2020

Accepted: April 24, 2020

Online Published: April 28, 2020

doi:10.5539/ibr.v13n5p95

URL: https://doi.org/10.5539/ibr.v13n5p95

\begin{abstract}
This paper examines the capital structure across different countries from 2005 to 2015 in Egypt and other three selected countries namely: Turkey, Brazil and Argentina. The book leverage sensitivity to the explanatory variables (profitability, firm size, tangibility, volatility, GDP growth, inflation and stock market development) was examined. Specifically, this paper documents the determinants of capital structure in Egyptian listed non-financial firms and investigates how capital structure decisions in three other countries who are one-step ahead in terms of economic development entertain any unique features.

Profitability was the only variable consistently highly significant with negative coefficient obtained in our regressions for four countries using GMM estimation method. Inconsistency of results for other variables prevailed. Findings reveal that Egyptian firms on average are not highly leveraged due to supply constraints on bank lending and demand constraints on consumer borrowing. The empirical evidence seems reasonably consistent with some versions of capital structure theory and other studies.
\end{abstract}

Keywords: Argentina, Brazil, capital structure, country-specific factors, Egypt, firm-specific factors, Generalized Method of Moments (System GMM), Turkey

\section{Introduction}

In pursuit of maximizing firm value, financial managers are charged with two main responsibilities: investment decisions and capital structure choices (Watson and Head 2010). In finance one of the most debatable topics is capital structure (Mostarac 2013). Capital structure decisions are critical for the financial soundness of the firm. Financial distress, liquidation and bankruptcy are the ultimate drawbacks that could materialize if wrong judgment occurred during financing decision of the firm's activity. Operating in a highly uncertain world makes it extremely difficult for any firm to achieve optimal capital structure (Al-Shubiri 2011). "Despite the fact that many researchers have devoted tremendous effort in understanding firms' financing policies \& hence realizing optimal capital structure; this is still a cloudy area and highly debatable with no specific guidelines in attaining best mixture of debt and equity" (Al-Shubiri 2011). Most of the academics and practitioners agree that firms work towards achieving a "target" capital structure, which could differ from one company to another and within an industry (Iqbal 2013).

Capital structure theory being the most controversial area of the financial management commenced more than 50 years with Modigliani and Miller's (M\&M) theory (1958). Since Modigliani and Miller's theory, there have been number of theories attempting to explain the mix of debt and equity used by companies to finance their business activities, like the trade-off theory, agency theory, signaling theory, pecking order theory and market timing theory. "They all differ in their relative emphasis on the key factors affecting the capital structure choice" (Mostarac 2013). Hence, corporate capital structure remains a puzzle (Myers, 1984).

Studying capital structure decision in transition market like Egypt, along with conducting cross-country analysis with other countries that are one step ahead in terms of economic development; is of great importance to managers, owners, lenders and policy makers (Youssef 2018). Capital structure is dynamic and depends on condition of the economy. Debt financing pattern in a developing country like Egypt signifies that changes in long-term debt and short-term debt components are not independent. To clarify, Eldomiaty (2008) findings reflect that firms in developing countries might borrow long-term debt partially to offset maturing short-term debt. As such, to resolve any suspicious interpretation in conducted analysis, this paper experiments leverage as "all debt". Total debt divided by total assets is used as dependent variable. 
The paper begins with proxies for determination of capital structure followed by a presentation for list of testable hypotheses for both internal factors (firm-specific) and external factors (macro-economic/ country-specific), in order to set framework for empirical results analysis. The core section of this paper starts with descriptive statistics for all sectors / aggregate results and secondarily by economic sector, followed by evaluations for results obtained from System GMM. During period under study Egypt faced revolution in 2011, as such its significance in affecting studied relationships between independent variables and leverage is accounted for as a dummy variable. Equal number of years prior and after Egypt revolution were covered in this study. In the conclusion the main results are discussed and suggestions for future research are presented.

\section{Literature Review}

\section{Theories of Capital Structure}

Modigliani and Miller (1958) classic theory was the drive for many other theories and debates on capital structure decisions. Irrelevance of capital structure in determining firm value and its future performance under the assumption of perfect and efficient capital market was proved in MM's first proposition. Given undebatable existence of corporate tax and market imperfection, MM's relaxed second proposition was introduced in 1963. Impact of taxation was accounted for in second proposition. In other words, inevitable presence of corporate tax signifies the fact that capital structure decision is relevant. Subsequently, trade-off theory by Modigliani and Miller was introduced in 1966 emphasizing on taxes. Firm's trade-off between the benefit of tax deductibility of interest referred to as debt tax shields and costs of financial distress. Since Modigliani and Miller, several other theories emerged to explain the mix between debt and equity used by corporations to finance their business activities. These theories as will be presented below are driven by three core economic problems / incentives namely, taxes, information and agency costs (Myers, 2001).

Jensen and Meckling (1976) presented "agency theory" which arose from the fact that realized benefit of tax shield from borrowing is not free of costs. This is specifically true for bankruptcy and agency costs resulting from debt financing. Focusing on agency costs, Jensen and Meckling associates this possible cost to primarily, conflict of relationships between mangers and shareholders. It is secondarily resulting from conflicts between debt holders and shareholders. Primarily form of conflict arises from the fact that managers will act in their own economic self-interest. This is attributable to the fact that managers (agents) have first-hand access to information and strive to maximize their own gains using company resources. Meanwhile, minimizing effort directed to the best interests of their principals / shareholders. Secondarily, form of conflict between debt holders and shareholders arise when there is risk of default. This form of conflict would materialize when shareholders / owners utilize borrowed funds from debt holders in riskier projects. This is referred to by Jensen and Meckling (1976) as "risk-shifting"; whereby higher risk increases the "upside" for stockholders and "downside" is absorbed by debt holders.

Ross (1977) "signaling theory" was built on information asymmetry originally developed by Jensen and Meckling (1976). Managers striving to maximize their own gains is the key driver for signaling theory that affects firm's financing decision process. "Signal" is referred to as the piece of private information delivered by managers / insiders to the public / outsiders. Delivered information doesn't necessarily include full picture of information accessible to managers / insiders. Hence, resulting in having the public / outsiders accessing limited information (whether positive or negative), which would hinder their ability in grasping equal benefits / gains like managers / insiders.

Myers and Majluf (1984) and Myers (1984) "pecking order theory" was also built on costs of adverse selection that results from information asymmetry between better-informed managers and less-informed investors. Such costs occur only in case of equity financing / issuing securities and are lower in case of debt. Target debt ratio under this theory does not exist and emphasis in capital choices depend on their costs. Capital choices / sources of funds are retained earnings, debt and equity. Focusing on costs of adverse selection, equity has the highest and most serious adverse selection, followed by debt and finally retained earnings being the safest that avoids this problem (Frank and Goyal, 2009). As such, when the requirement of external financing arises, the firm will work down the pecking order, from the safest namely retained earnings. As such, firm would prefer debt to equity. Pecking order theory explains why debt presents bulk of external financing; along with illustrating why borrowing is less for more profitable firms. Given non-existence of optimal debt level under pecking order theory, key driver behind less borrowing for more profitable firms is attributed to higher accessibility for internal financing and not due to having a low target debt ratio. This implies rejection of pecking order theory advocates to the target capital structure proposed earlier by Modigliani and Miller (1958).

Baker and Wurgler (2002) "market timing theory" emphasizes significance to time the market, whereby equity 
market timing affects capital structure. Main findings of this theory is that low leverage firms are those that issued equity when their market valuations were high, as measured by market-to-book ratio. Also, when market conditions are unfavorable with low market value, firms will refrain from issuing equity and instead will repurchase equity at low prices. Approach of market timing theory is more sophisticated than previously presented theories. It places no emphasis on neither optimal capital structure nor costs of adverse selection that results from information asymmetry. This is sequentially proposed by trade-off theory and the pecking order theory.

Background on capital structure decisions are mostly based on developed economies with homogeneous institutional structures (Booth et al., 2001). International studies comparing differences in the capital structure between countries reinforced that conventional theories work well in similar economies with developed legal environment and high level of economic development (Jong, 2008). A remarkable number of studies were conducted on developed economies, as well as a considerable number of studies though with less intensity were conducted on developing countries. Findings prevail two-sided argument, with similarities in effect of firm-specific factors on capital structure decision on one hand, irrespective of level of economic development. Variation, on the other hand, based on country-specific factors reflects difference in institutional factors.

Drawing lessons from more developed institutions and examining their applicability is particularly important given that Egypt witnessed different stages of economic development. The 2005-2011 period witnessed a growth period followed with stagnation during the Arab Spring period and its aftermath (2011-2015). Lately the country has witnessed an awakening which was an outcome for several reforms. This includes reduction of energy subsidies, tax reform, strengthened business environment, as well as greater political stability after years of turmoil.

\section{Proxies for the Determination of Capital Structure}

Theoretical and empirical studies have shown that profitability, firm size, tangibility, volatility, GDP growth, inflation and stock market development affect capital structure. On the relationship between these factors and companies' capital structure, Rajan and Zingles (1995) referred to Harris and Raviv (1991) in selection of factors correlated to leverage; stating that consensus is "leverage increases with fixed assets, nondebt tax shields, investment opportunities and firm size and decreases with volatility, advertising expenditure, the probability of bankruptcy, profitability and uniqueness of product." Four of mentioned variables were used in addition to other factors that proved to be highly correlated with leverage in previous studies (e.g Harris and Raviv (1991), Booth et al. (2001), Jong (2008)).

\section{Profitability}

Although much theoretical work has been done since Modigliani and Miller (1958), no consistent predictions have been reached with respect to relationship between profitability and leverage. There is an expected negative relationship between profitability and leverage in accordance to pecking order theory. A positive relationship is expected based on the static trade-off and agency theory. Predicted positive relation between leverage and profitability is further confirmed by Jensen and Meckling (1976) "agency theory" and later by Jensen's (1986) "free cash flow theory".

In contrast to theoretical studies, most empirical studies show that leverage is negatively related to profitability. This is evidenced by findings from studies on developed countries \& specifically US \& Japan by Kester (1986). Titman and Wessels (1988), and Friend and Lang (1988) studies focused on US firms. Other findings related to developed countries were conducted by Wald (1999), Rajan and Zingles (1995). In this paper, profitability will be defined as earnings before interest and tax (EBIT) scaled by total assets.

\section{Firm Size}

Two opposing arguments validated theoretically initially by Trade-off theory predicting a positive relationship between firm size and leverage. Larger firms are more diversified hence, have more stability and less volatility in cash flow, which lessens default risk. Whereas, pecking order theory, predicts a negative relationship due to less asymmetric information in large firms with more information provided to outside investors compared to smaller firms. As such, resulting in higher preference for equity issuance relative to debt.

Empirical studies following the same lead of Rajan and Zingales (1995): "size may be a proxy for (inverse) probability of default" include: Booth et al. (2001), Wald (1999) and Marsh (1982). This paper uses natural logarithm of assets as a measurement of firm size; following Jong (2008), Booth et al. (2001), Rajan and Zingales (1995) and Titman and Wessels (1988). 


\section{Tangibility}

On the relationship between tangibility and capital structure, a positive relationship to leverage, except for agency theory. The positive relationship between tangibility and the level of debt is predicted by both the trade-off theory and the pecking order theory. This is consistent with the fact that firms with relatively safe, tangible assets that can be collateralized tend to borrow more than firms with risky, intangible assets. Predicting the relationship between tangibility and leverage from perspective of agency theory has two folds (both positive and negative relationship).

Empirical studies confirming positive relationship include Wald (1999), Rajan and Zingales (1995), Friend and Lang (1988), Long and Maltiz (1985). On the other hand, Booth et al. (2001), (Myers, 2001) Titman and Wessels (1988) confirmed negative relationship as reflected in argument: "growth opportunities are capital assets that add value to a firm but cannot be collateralized". This paper uses fixed assets divided by total assets as a measure for tangibility, following Marsh (1982), Rajan and Zingales (1995) and Jong (2008).

\section{Volatility}

Volatility or business risk is a proxy for the probability of financial distress. Many previous studies reflected a negative relationship between leverage and volatility. Firms with more volatile cash flows face higher expected costs of financial distress \& have less book leverage (Fama and French, 2002; Deesomsak et al., 2004). Frank and Goyal (2009) also added that probability of foregoing interest tax shields increases when earnings are below tax shields. This paper follows Wald (1999) and Jong (2008) measurement of business risk defined as the standard deviation of operating income over book value of total assets during the sample period.

\section{GDP Growth}

There is no consistent predictions with respect to relationship between GDP growth and leverage. There is an expected positive relationship between GDP growth and leverage in accordance to trade-off theory, whereas a negative relationship is expected based on agency theory and pecking order theory. Agency theory predicts leverage to be countercyclical / increasing despite of economic downturn, as debt supports in resolving agency costs of managerial discretion. As for Pecking order theory, a negative relationship reflecting a decline in leverage during expansions; due to increase in internal funds \& hence, there is lower need for external finance.

Empirical studies confirming positive relationship includes Booth et al. (2001), Jong (2008) and Frank and Goyal (2009). A study on Nepalese firms was conducted by Gajurel (2005) validating that GDP growth was negatively related to leverage ratio consistent with findings by Korajczyk and Levy (2003). Following common practice, GDP growth is calculated by the percent change in the annual real GDP.

\section{Inflation}

Trade-off theory and Market timing theory predict a positive relationship between leverage and expected inflation. This is driven from the fact that inflation-induced increase in nominal interest rate increases tax advantage of debt financing. In addition, high expected inflation leads to higher debt issuance and more short-term debt in terms of debt composition. On the other hand, Booth et al. (2001) findings in study of capital structures in developing countries, showed negative relation between inflation and leverage.

Empirical studies supporting positive relationship include Frank and Goyal (2009), Graham and Harvey (2001), Marsh (1982) and Faulkender (2005). Following previous studies, percentage change in the annual consumer price index (CPI) is used as a rough proxy for expected inflation. Using data of realized inflation like previous studies is intended to resolve unavailability of expected inflation data for the whole sample period.

\section{Stock Market Development}

Theoretically and as denoted by Demirguc-kunt and Maksimovic (1996) in their study on stock market development and financing choices of firms: "finance literature suggests that stock markets serve important functions even in those economies in which well-developed banking sector already exists, the reason being that equity and debt financing are in general not perfect substitutes". Their findings on an aggregate level when taking all countries in sample under study, is consistent with majority of empirical studies evidencing significant negative correlation between stock market development and leverage. However, being more precise by breaking used sample into subsamples namely, developed and developing stock markets; led to mixed results.

Majority of empirical evidence find a significant negative relationship between leverage and stock market development (Booth et al., 2001; Deesomsak et al., 2004; Jong, 2008; Frank and Goyal, 2009). Mixed results on this variable was also found in previous studies (e.g, Rajan and Zingales, 1995; Demirguc-kunt and Maksimovic, 1996). Following previous studies, stock market development is measured in this paper by the ratio of stock market capitalization to GDP. 
Relationship between selected capital structure determinants and leverage both theoretically and empirically is presented in below table.

Table 1. Predicted signs and results

\begin{tabular}{|c|c|c|c|}
\hline Proxy (Abbreviation) & Definitions & $\begin{array}{l}\text { Theoretical } \\
\text { predicted signs }\end{array}$ & $\begin{array}{c}\text { Major empirical } \\
\text { studies' results }\end{array}$ \\
\hline \multicolumn{4}{|l|}{$\begin{array}{l}\text { Internal factors of } \\
\text { capital structure }\end{array}$} \\
\hline Profitability (ROA) & $\begin{array}{l}\text { Operating income divided by book value } \\
\text { of total assets }\end{array}$ & $+/-$ & - \\
\hline Firm Size & Natural logarithm of Sales & $+/-$ & + \\
\hline Tangibility & Fixed assets divided by total assets & $+/-$ & + \\
\hline Volatility & $\begin{array}{l}\text { Standard deviation of operating income } \\
\text { over book value of total assets }\end{array}$ & - & - \\
\hline \multicolumn{4}{|l|}{$\begin{array}{l}\text { External factors of } \\
\text { capital structure }\end{array}$} \\
\hline GDP Growth & Percent change in the annual real GDP & $+/-$ & + \\
\hline Inflation & $\begin{array}{l}\text { Percentage change in annual consumer } \\
\text { price index }(\mathrm{CPI})\end{array}$ & $+/-$ & + \\
\hline $\begin{array}{ll}\text { Stock } & \text { market } \\
\text { development }\end{array}$ & $\begin{array}{l}\text { Ratio of stock market capitalization to } \\
\text { GDP }\end{array}$ & $+/-$ & - \\
\hline
\end{tabular}

Above table sums up outcome of theoretical predicted signs and the results of previous empirical studies.

\section{Development of Hypotheses and Determination of Capital Structure}

The hypothesis development is based primarily on similar expectations of outcomes as those obtained from studies conducted on developing countries and secondarily on significance of drawing lessons from countries that are one-step head in economic development relative to Egypt. This is an attempt to ensure sustainability of advancement in Egyptian economy.

List of testable hypotheses for both internal factors (firm-specific) and external factors (macro-economic / country specific) are presented below, which sets framework for empirical results analysis.

\section{Internal factors / Firm-specific factors}

Hypothesis $\mathrm{H}_{1}$ Firm size has a positive effect on leverage

Hypothesis $\mathrm{H} 2$ Profitability has a negative effect on leverage

Hypothesis $\mathrm{H}_{3}$ Tangibility has a positive effect on leverage

Hypothesis $\mathrm{H}_{4}$ Business risk has a negative effect on leverage

External factors / Macroeconomic - country specific factors

Hypothesis $\mathrm{H}_{5}$ GDP growth rate has a positive effect on leverage

Hypothesis $\mathrm{H}_{6}$ Inflation has a positive effect on leverage

Hypothesis $\mathrm{H}_{7}$ Stock market development has a negative effect on leverage

Equal effects between countries during period under study

Hypothesis $\mathrm{H}_{8}$ All variables' coefficients (both internal \& external variables) are the same between countries 


\section{Data Description and Methodology}

\subsection{Data}

The study uses annual data of non-financial listed companies from 2005 until 2015. Financial companies and banking sector are excluded due to uniqueness of their financing / capital structure choices (Gaud et al., 2005). Bank capital role as a form of self-insurance provides both a buffer against unforeseen losses and an incentive to manage risk-taking. As such regulated banks voluntarily choose to maintain capital in excess to the minimum required. Capital structure in banking sector is a special topic which has been addressed for the Egyptian banks by Alber (2018).

Table 2 summarizes classification of firms based on industry classification. The main source of data used in Thomson Reuters DataStream.

Table 2. Classification of used sample \& number of firms in each sector

\begin{tabular}{lcccc}
\hline Sector & Egypt & Turkey & Brazil & Argentina \\
\hline Industrials & 26 & 72 & 91 & 39 \\
Consumer Non-Cyclicals & 18 & 59 & 42 & 24 \\
Basic Materials & 13 & 46 & 22 & 11 \\
Others & 18 & 101 & 73 & 29 \\
\hline All sectors & 75 & 278 & 228 & 103 \\
\hline
\end{tabular}

Turkey has the highest number of firms and Egypt has the lowest among selected countries.

\subsection{Selected Countries}

Selection of countries to conduct cross-country comparison, along with drawing lessons from slightly better institutions and examining applicability to Egypt; was based on stages of development set by Global Competitiveness report 2014-2015. Countries are classified in addressed report into three categories namely; Factor-driven economies, Efficiency-driven economies and Innovation driven economies. Between first and second stage, there is "Transition Stage 1-2" and between second and third stage, there is "Transition Stage 2-3". Hence, in total if we account for transition stages, we have 5 stages of economic development using Global Competitiveness Index (GCI). In this paper we will stick to specified classifications by GCI when referring to countries under study. Egypt is classified under second stage of development - "Efficiency-driven". Turkey, Brazil and Argentina are classified in the "Transition Stage 2-3" which is right after Egypt's current classification. GCI classifies countries based on three key indicators scoring namely; basic requirements, efficiency enhancers, innovation \& sophistication. Within each of the three key indicators, there are detailed scoring for 12 pillars displayed in the report for each country on standalone basis; such as infrastructure pillar, macroeconomic environment pillar, health and primary education pillar, financial market development pillar,...etc. Key macro-economic indicators for selected countries is presented below.

Table 3. The Global Competitiveness Report 2014-2015

\begin{tabular}{|l|l|l|l|l|}
\hline Key Indicators & Egypt & Turkey & Argentina & Brazil \\
\hline Population (Millions) & 84.2 & 76.5 & 42 & 198.3 \\
GDP (US \$ billions) & 271.4 & 827.2 & 488.2 & 2,243 \\
GDP Per Capita (US \$) & 3,226 & 10,815 & 11,766 & 11,311 \\
\hline Index Overall Score (1-7) & 3.7 & 4.8 & 4.1 & 4.4 \\
Basic Requirements & & & & \\
\hline Efficiency Enhancers & 3.6 & 4.4 & 3.8 & 4.5 \\
\hline Innovation \& Sophistication Factors & 3.2 & 3.9 & 3.4 & 3.8 \\
\hline
\end{tabular}




\subsection{The Model}

To examine the influence of capital structure determinants on capital structure in a panel dataset of 4 countries under study, the model used under GMM estimation is:

$$
\begin{gathered}
\gamma_{i t}=\beta_{1} \gamma_{i, t-1}+\beta_{2} x_{i t}+\varepsilon_{i t} \\
\mathrm{i}=1, \ldots, \mathrm{n} ; \mathrm{t}=1,2,3, \ldots 11
\end{gathered}
$$

According to above equation, $\gamma_{i t}$ is the dependent variable represented by the debt ratio as a percentage of total debt to total assets. $\gamma_{i, t-1}$ is the dependent variable lagged value and it implies that current debt ratio is a function of previous value. As for $\mathrm{i}(\mathrm{i}=1, \ldots, \mathrm{n})$ represents the individual firms of countries under study and $\mathrm{t}$ denotes the time period. $x_{i t}$ represents independent variables both internal \& external, as will be specified in following section. $\beta$ is constant for all $\mathrm{i}$ and $\mathrm{t} \&$ it is the unknown parameter which is estimated from the effects of the regressor $x_{i t}$ in time $\mathrm{t}$ for individual i. $\varepsilon_{i t}$ is the unobserved error term from disturbances factors of the observed individual.

\section{Results}

This section will present descriptive statistics, VIF results; then results obtained from GMM are presented.

\subsection{Descriptive Statistics}

Table 4 presents descriptive statistics over sample period 2005 to 2015. What was deducted from presented results is stated below. Descriptive statistics by economic sector is presented in appendix.

\begin{tabular}{|c|c|c|c|c|c|c|c|c|c|}
\hline Country & Statistic & $\begin{array}{c}\text { Book } \\
\text { Leverage }\end{array}$ & Size & Profitability & Tangibility & Volatility & GDP & Inflation & Market \\
\hline \multirow{6}{*}{ Egypt } & Obs. & 776 & 782 & 759 & 779 & 779 & 825 & 825 & 750 \\
\hline & Mean & 0.2301 & 11.415 & 0.0862 & 0.3789 & 0.0675 & 0.164 & 0.0994 & 0.4361 \\
\hline & Median & 0.2034 & 11.273 & 0.0831 & 0.3809 & 0.0454 & 0.1635 & 0.1009 & 0.3072 \\
\hline & SD & 0.1739 & 1.6985 & 0.0923 & 0.2222 & 0.074 & 0.0414 & 0.0321 & 0.2948 \\
\hline & Min. & 0 & 5.9108 & -0.3043 & 0.0001 & 0.0071 & 0.0876 & 0.0479 & 0.1659 \\
\hline & Max. & 0.9276 & 15.4847 & 0.484 & 0.8962 & 0.5841 & 0.2103 & 0.1831 & 1.0674 \\
\hline \multirow{6}{*}{ Turkey } & Obs. & 2970 & 2966 & 2924 & 2972 & 2973 & 3058 & 3058 & 3058 \\
\hline & Mean & 0.2626 & 12.0739 & 0.0709 & 0.3651 & 0.1106 & 0.0577 & 0.0829 & 0.2904 \\
\hline & Median & 0.2053 & 12.0087 & 0.0626 & 0.3496 & 0.0664 & 0.063 & 0.0857 & 0.2912 \\
\hline & SD & 0.3992 & 1.9369 & 0.2072 & 0.2293 & 0.1773 & 0.0435 & 0.012 & 0.0824 \\
\hline & Min. & 0 & 2.9444 & -3.4012 & 0 & 0.0082 & -0.0597 & 0.0625 & 0.1538 \\
\hline & Max. & 10.7343 & 17.6863 & 7.9242 & 1.4291 & 2.6703 & 0.105 & 0.1045 & 0.4211 \\
\hline \multirow{6}{*}{ Brazil } & Obs. & 2451 & 2435 & 2431 & 2431 & 2451 & 2508 & 2508 & 2508 \\
\hline & Mean & 0.3326 & 13.2554 & 0.0794 & 0.3258 & 2.1852 & 0.1077 & 0.0581 & 0.5455 \\
\hline & Median & 0.3046 & 13.3528 & 0.0862 & 0.3015 & 0.0699 & 0.1087 & 0.0568 & 0.4979 \\
\hline & SD & 0.2781 & 1.9484 & 0.1411 & 0.2295 & 80.7963 & 0.0333 & 0.014 & 0.2063 \\
\hline & Min. & 0 & 3.5553 & -2.3876 & 0 & 0.0122 & 0.0383 & 0.0364 & 0.272 \\
\hline & Max. & 4.0423 & 17.9406 & 0.6606 & 0.9466 & 3859.311 & 0.1659 & 0.0903 & 0.9804 \\
\hline \multirow{6}{*}{ Argentina } & Obs. & 1089 & 1085 & 1080 & 1089 & 1089 & 1133 & 1133 & 1133 \\
\hline & Mean & 0.242 & 12.385 & 0.0941 & 0.4919 & 0.0908 & 0.2562 & 1.58 & 0.1371 \\
\hline & Median & 0.2167 & 12.2329 & 0.0853 & 0.5272 & 0.0741 & 0.2693 & 1.78 & 0.1143 \\
\hline & SD & 0.1748 & 1.6308 & 0.099 & 0.255 & 0.0695 & 0.0723 & 0.5906 & 0.056 \\
\hline & Min. & 0 & 1.9459 & -0.2895 & 0.0062 & 0.0133 & 0.0855 & 0.68 & 0.0627 \\
\hline & Max. & 1.0211 & 15.4967 & 0.435 & 0.922 & 0.5137 & 0.3676 & 2.73 & 0.2395 \\
\hline
\end{tabular}

Table 4. Descriptive Statistics

Notes: This table represents the descriptive statistics of all variables (all sectors), i.e mean, median and standard deviation for both dependent and independent variables. 
The mean of book leverage ratio of the firms from all countries varies from $23 \%$ to $33 \%$ over the sample period 2005 to 2015.

In descriptive statistics by economic sector/industry, mean of total debt ratio of the firms from all 4 countries varies from lowest level of 0.144 for Turkey under "Basic Materials" to highest level of 0.37 still for Turkey under "Consumer Non-cyclicals". Egyptian companies have an average total debt ratio of $23 \%$ which is the lowest, as reflected by below graph. Hence, validating preference of equity financing in Egypt over debt.

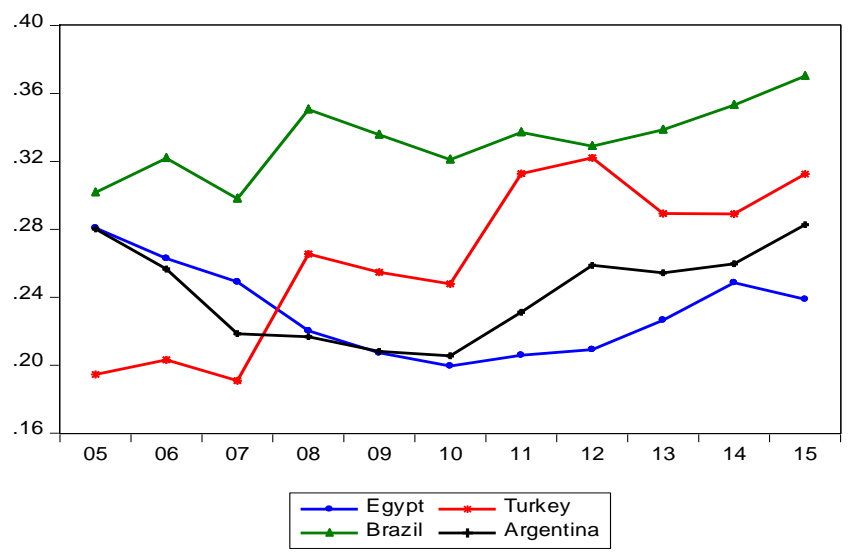

Figure 1. Debt ratio trends over 11 years

For firm-specific independent variables, no single country consistently pertains highest or lowest values for the mean, median, standard deviation, or range of a specific independent variable; across the four sectors. As such, countries alternate in lowest or highest measure for range of addressed independent variable and accordingly deviation. This is expected, as pooled / combined firms under each sector is different in size. To illustrate, Egypt has lowest standard deviation for "size" under "consumer non-cyclicals", which is validated by having the lowest range compared to other countries. Argentina under "basic materials" sector reflects the lowest standard deviation for "size", along with lowest range. Hence, confirming that most of size ratios are very close to the average. This applies to other independent variables under investigation; with almost all measures being close the average (mean).

For country-specific independent variables, any variable for a specific country (for example GDP growth) will have the same ranking (highest or lowest measure relative to other countries) for mean, median, standard deviation and range; across the four sectors. Only variation will be in number of observations. To illustrate, Argentina has lowest standard deviation of 0.05 for "stock market development", along with lowest range under the four sectors. In addition, unity in measurements for any macro-economic variable across the four economic sectors apply.

Variance Inflation Factor (VIF) results presented in table 5 indicate the regression equation is free of multicollinearity over the sample period as VIF is less than 5.

Table 5. VIF Values

\begin{tabular}{lcccc}
\hline & Egypt & Turkey & Brazil & Argentina \\
\hline Lagged Book Leverage & 2.0245 & 1.1884 & 1.0659 & 1.8293 \\
Size & 1.7841 & 1.2369 & 1.1548 & 1.3253 \\
Profitability & 1.6561 & 1.3364 & 1.045 & 1.3083 \\
Tangibility & 1.0248 & 1.1015 & 1.0261 & 1.5512 \\
Volatility & 1.5148 & 1.252 & 1.0606 & 1.3607 \\
GDP & 1.3044 & 1.5191 & 1.5158 & 1.5914 \\
Inflation & 1.5008 & 1.3751 & 3.6908 & 3.3446 \\
Market & 3.6674 & 1.1682 & 2.9458 & 2.7155 \\
Revolution & 3.7651 & --- & --- & -- \\
\hline
\end{tabular}




\subsection{Main Results from GMM}

Table 6 presents GMM estimations obtained for each country for all sectors combined. Tables 7 till 10, represent results of economic sectors effect on capital structure.

Table 6. Determinants of capital structure using GMM Estimation (All Sectors)

\begin{tabular}{|c|c|c|c|c|}
\hline Variable & Egypt & Turkey & Brazil & Argentina \\
\hline \multirow[t]{2}{*}{ Lagged Book Leverage } & 0.1640 & 0.8621 & 0.7092 & 0.6270 \\
\hline & $(0.0072)^{* * *}$ & $(0.0767)^{* * *}$ & $(0.0172)^{* * *}$ & $(0.0459)^{* * *}$ \\
\hline \multirow[t]{2}{*}{ Size } & 0.0084 & 0.0583 & 0.0597 & 0.0427 \\
\hline & $(0.0032)^{* *}$ & $(0.0176) * * *$ & $(0.0163)^{* * *}$ & $(0.0207)^{* *}$ \\
\hline \multirow[t]{2}{*}{ Profitability } & -0.3431 & -0.4914 & -0.5313 & -0.4672 \\
\hline & $(0.0369)^{* * *}$ & $(0.0672)^{* * *}$ & $(0.0374)^{* * *}$ & $(0.0744)^{* * *}$ \\
\hline \multirow[t]{2}{*}{ Tangibility } & 0.7080 & 0.9421 & 0.3581 & -0.1387 \\
\hline & $(0.1085)^{* * *}$ & $(0.1770)^{* * *}$ & $(0.0597)^{* * *}$ & $(0.2466)$ \\
\hline \multirow[t]{2}{*}{ Volatility } & 0.7080 & 0.9421 & 0.3581 & -0.1387 \\
\hline & $(0.1085)^{* * *}$ & $(0.1770)^{* * *}$ & $(0.0597)^{* * *}$ & $(0.2466)$ \\
\hline \multirow[t]{2}{*}{ GDP } & -0.1691 & 13.4276 & 2.4327 & 0.4176 \\
\hline & $(0.0274)^{* * *}$ & $(6.3459) *$ & $(1.1259)^{*}$ & $(1.3080)$ \\
\hline \multirow[t]{2}{*}{ Inflation } & 0.3020 & 58.8916 & 11.0435 & 0.4658 \\
\hline & $(0.0300)^{* * *}$ & $(25.1114)^{* *}$ & $(4.7658) *$ & $(0.2314)^{*}$ \\
\hline \multirow[t]{2}{*}{ Market } & 0.1780 & -3.1323 & 0.4888 & 8.0602 \\
\hline & $(0.0091)^{* * *}$ & $(1.5601)^{*}$ & $(0.2597) \dagger$ & $(2.7463)^{* *}$ \\
\hline \multirow[t]{2}{*}{ Revolution } & 0.0402 & --- & --- & -- \\
\hline & $(0.0029)^{* * *}$ & --- & --- & --- \\
\hline Observations & 599 & 2586 & 2149 & 958 \\
\hline Sargan/Hansen Test & 65.7931 & 36.5205 & 53.7570 & 60.4651 \\
\hline p-value & 0.130 & 0.906 & 0.072 & 0.126 \\
\hline $\operatorname{AR}(\mathbf{1})$ & -3.2114 & -3.3932 & -8.5803 & -2.5866 \\
\hline p-value & 0.0013 & 0.0007 & 0.0000 & 0.0097 \\
\hline $\mathbf{A R}(2)$ & 0.5473 & -0.6131 & -0.7047 & 1.9488 \\
\hline p-value & 0.5842 & 0.5398 & 0.4810 & 0.0513 \\
\hline Wald Test $\left(\chi^{2}\right)$ & 1304.14 & 213.47 & 2606.32 & 407.33 \\
\hline p-value & 0.0000 & 0.0000 & 0.0000 & 0.0000 \\
\hline
\end{tabular}

Notes: Standard errors are shown below the coefficients. ${ }^{* * *} \mathrm{p}<0.001,{ }^{* *} \mathrm{p}<0.01,{ }^{*} \mathrm{p}<0.05, \dagger \mathrm{p}<0.1$

Overall model statistical significance both on aggregate level (all sectors) and on economic sector level is confirmed by "Wald Test" at the 0.001 highest significance level $(\mathrm{p}<0.001)$. Validity of instrumental variables is confirmed by Sargan / Hansen test, with p-value $>0.05$ for the 4 countries under study. Diagnostic tests include: first, "Arellano-Bond Serial Correlation Test" which includes primarily "Serial Correlation Test (AR 1), with p-value $<0.05$ for the 4 countries under study, hence confirming absence of serial correlation. Second, "Robustness of First Order Lag (AR 2), with p-value > 0.05 for the 4 countries under study, hence confirming $1^{\text {st }}$ order lag is sufficient given absence of serial correlation. Diagnostic tests results \& goodness of fit measures validates efficiency of estimate for the 4 countries under study both on aggregate level (all sectors) and on economic sectors level. 
Table 7. Determinants of capital structure using GMM estimation (Industrials)

\begin{tabular}{|c|c|c|c|c|}
\hline Variable & Egypt & Turkey & Brazil & Argentina \\
\hline Lagged Book Leverage & 0.3809 & 0.4180 & $\mathbf{0 . 0 3 8 7}$ & 0.4899 \\
\hline & $(0.0503) * * *$ & $(0.0912) * * *$ & $(0.0044) * * *$ & $(0.1369) * * *$ \\
\hline Size & -0.0151 & -0.1019 & -0.0123 & -0.0032 \\
\hline & $(0.0082) \dagger$ & $(0.0361)^{* *}$ & $(0.0032) * * *$ & $(0.0251)$ \\
\hline Profitability & -0.5177 & -0.6118 & -0.7732 & -0.2316 \\
\hline & $(0.0998) * * *$ & $(0.1325)^{* * *}$ & $(0.0155)^{* * *}$ & $(0.0571)^{* * *}$ \\
\hline Tangibility & 0.2148 & -0.1652 & 0.1124 & -0.1760 \\
\hline & $(0.0673) * * *$ & $(0.0487) * * *$ & $(0.0077) * * *$ & $(0.0796) *$ \\
\hline Volatility & $\begin{array}{l}-\mathbf{- 0 . 5 8 4 6} \\
(0.4192)\end{array}$ & $\begin{array}{l}\mathbf{- 1 . 1 1 8 0} \\
(03839) * *\end{array}$ & $\begin{array}{l}\mathbf{0 . 1 9 5 9} \\
(0.1244 * * *\end{array}$ & $\mathbf{0 . 3 8 6 7}$ \\
\hline GDP & -0.3439 & -1.3049 & 0.1632 & 0.0617 \\
\hline & $(0.1136) * *$ & $(1.0033)$ & $(0.0137) * * *$ & $(0.0806)$ \\
\hline Inflation & 0.2028 & -12.6364 & -0.4032 & -0.0249 \\
\hline & $(0.1897)$ & $(4.8015)^{* *}$ & $(0.0571)^{* * *}$ & $(0.0193) \dagger$ \\
\hline Market & $\mathbf{0 . 2 2 0 6}$ & $\mathbf{0 . 0 6 8 8}$ & $\mathbf{- 0 . 0 6 7 9}$ & $\mathbf{- 0 . 2 1 0 9}$ \\
\hline Revolution & 0.0456 & --.- & $-.-0041)$ & $-(0.10 / 4)$ \\
\hline & $(0.0131) * * *$ & --- & --- & --- \\
\hline Observations & 192 & 662 & 843 & 366 \\
\hline Sargan/Hansen Test & 62.2609 & 33.4589 & 74.9297 & 25.5984 \\
\hline p-value & 0.206 & 0.1200 & 0.0558 & 0.5951 \\
\hline $\mathbf{A R}(\mathbf{1})$ & -5.0270 & -7.0349 & -6.2050 & -1.9644 \\
\hline p-value & 0.0000 & 0.0000 & 0.0000 & 0.0495 \\
\hline $\mathbf{A R}(2)$ & 0.7648 & 0.2999 & 0.4845 & 0.4980 \\
\hline p-value & 0.4444 & 0.7642 & 0.6281 & 0.6185 \\
\hline Wald Test $\left(\chi^{2}\right)$ & 504.91 & 216.84 & 4474.69 & 44.90 \\
\hline p-value & 0.0000 & 0.0000 & 0.0000 & 0.0000 \\
\hline
\end{tabular}

Notes: Standard errors are shown below the coefficients. ${ }^{* * *} \mathrm{p}<0.001,{ }^{* *} \mathrm{p}<0.01,{ }^{*} \mathrm{p}<0.05, \dagger \mathrm{p}<0.1$

Table 8. Determinants of capital structure using GMM Estimation (Consumer Non-Cyclicals)

\begin{tabular}{l|l|l|l|l}
\hline Variable & \multicolumn{1}{c}{ Egypt } & \multicolumn{1}{c}{ Turkey } & \multicolumn{1}{c}{ Brazil } & \multicolumn{1}{c}{ Argentina } \\
\hline Lagged Book Leverage & $\mathbf{0 . 4 7 8 6}$ & $\mathbf{1 . 1 7 8 8}$ & $\mathbf{0 . 1 0 5 8}$ & $\mathbf{0 . 5 1 3 7}$ \\
& $(0.0529)^{* * *}$ & $(0.0087)^{* * *}$ & $(0.0060)^{* * *}$ & $(0.0619)^{* * *}$ \\
Size & $\mathbf{0 . 0 3 8 1}$ & $\mathbf{0 . 0 6 7 3}$ & $\mathbf{- 0 . 0 0 6 3}$ & $\mathbf{0 . 0 9 7 1}$ \\
Profitability & $(0.0179)^{*}$ & $(0.0055)^{* * *}$ & $(0.0059)$ & $(0.0197)^{* * *}$ \\
& $\mathbf{- 0 . 1 3 6 6}$ & $\mathbf{- 0 . 7 6 7 9}$ & $\mathbf{- 0 . 1 9 8 1}$ & $\mathbf{- 0 . 7 0 9 7}$ \\
Tangibility & $(0.0812) \dagger$ & $(0.0049)^{* * *}$ & $(0.0140)^{* * *}$ & $(0.0937)^{* * *}$ \\
& $\mathbf{0 . 9 4 4 2}$ & $\mathbf{0 . 1 7 8 7}$ & $\mathbf{0 . 2 2 5 4}$ & $\mathbf{- 0 . 1 1 1 9}$ \\
Volatility & $(0.3038)^{* *}$ & $(0.0149)^{* * *}$ & $(0.0186)^{* * *}$ & $(0.2820)$ \\
GDP & $\mathbf{0 . 9 4 4 2}$ & $\mathbf{0 . 1 7 8 7}$ & $\mathbf{0 . 2 2 5 4}$ & $\mathbf{- 0 . 1 1 1 9}$ \\
& $(0.3038)^{* *}$ & $(0.0149)^{* * *}$ & $(0.0186)^{* * *}$ & $(0.2820)$ \\
Inflation & $\mathbf{- 0 . 1 7 3 6}$ & $\mathbf{- 0 . 6 3 4 9}$ & $\mathbf{- 0 . 1 1 6 5}$ & $\mathbf{0 . 0 0 4 5}$ \\
& $(0.0841)^{*}$ & $(0.0366)^{* * *}$ & $(0.0288)^{* * *}$ & $(0.0235)$ \\
Market & $\mathbf{0 . 6 3 3 2}$ & $\mathbf{- 3 . 7 8 5 5}$ & $\mathbf{- 1 . 0 4 2 2}$ & $\mathbf{- 0 . 0 3 3 0}$ \\
& $(0.2089)^{* *}$ & $(0.1806)^{* * *}$ & $(0.1774)^{* * *}$ & $(0.0126)^{* *}$ \\
Revolution & $\mathbf{0 . 0 7 4 6}$ & $\mathbf{- 0 . 1 9 0 1}$ & $\mathbf{- 0 . 1 1 1 0}$ & $\mathbf{0 . 2 9 3 2}$ \\
& $(0.0307)^{* *}$ & $(0.0186)^{* * *}$ & $(0.0061)^{* * *}$ & $(0.0982)^{* *}$ \\
\hline Observations & $\mathbf{0 . 0 8 2 8}$ & --- & -- & -- \\
Sargan/Hansen Test & $(0.0148)^{* * *}$ & --- & --- & - \\
p-value & 145 & 535 & 409 & 214 \\
AR(1) & 66.2679 & 52.2428 & 35.9912 & 11.6460 \\
p-value & 0.122 & 0.0618 & 0.1155 & 0.0703 \\
AR(2) & -4.2589 & -8.6801 & -5.3662 & -4.7927 \\
p-value & 0.0000 & 0.0000 & 0.0000 & 0.0000 \\
Wald Test $\left(\chi^{2}\right)$ & 0.2014 & -0.8236 & -1.9125 & -1.3007 \\
p-value & 0.8404 & 0.4102 & 0.0558 & 0.1934 \\
\hline
\end{tabular}

Notes: Standard errors are shown below the coefficients. ${ }^{* * *} \mathrm{p}<0.001,{ }^{* *} \mathrm{p}<0.01,{ }^{*} \mathrm{p}<0.05, \dagger \mathrm{p}<0.1$ 
Table 9. Determinants of capital structure using GMM Estimation (Basic Materials)

\begin{tabular}{|c|c|c|c|c|}
\hline Variable & Egypt & Turkey & Brazil & Argentina \\
\hline Lagged Book Leverage & 0.3870 & $\mathbf{0 . 3 3 6 0}$ & 0.4960 & $\mathbf{0 . 5 3 6 3}$ \\
\hline Size & 0.1888 & -0.0109 & 0.0920 & $(0.0567$ \\
\hline & $(0.0167)^{* * *}$ & $(0.0190)$ & $(0.0189) * * *$ & $(0.0193)^{* *}$ \\
\hline Profitability & -1.1723 & -0.1513 & -0.5352 & -0.5210 \\
\hline & $(0.0676) * * *$ & $(0.0356) * * *$ & $(0.1313) * * *$ & $(0.0455)^{* * *}$ \\
\hline Tangibility & 0.1329 & -1.3287 & 0.5326 & 1.2961 \\
\hline . & $(0.2738)$ & $(0.3395)^{* * *}$ & $(0.1012)^{* * * *}$ & $(0.2775)^{* * *}$ \\
\hline Volatility & 0.1329 & -1.3287 & $\mathbf{0 . 5 3 2 6}$ & 1.2961 \\
\hline GDP & 0.5296 & 0.2126 & -0.2732 & $(0.2 / 75)^{-19}$ \\
\hline & $(0.0612)^{* * *}$ & $(0.0277)^{* * *}$ & $(0.0957)^{* *}$ & $(0.0594)$ \\
\hline Inflation & 0.2127 & 1.0414 & -0.9206 & -0.0053 \\
\hline & $(0.1435) \dagger$ & $(0.0774) * * *$ & $(0.5583) \dagger$ & $(0.0078)$ \\
\hline Market & 0.3164 & -0.2762 & -0.1023 & -0.0335 \\
\hline & $(0.0658) * * *$ & $(0.0083)^{* * * *}$ & $(0.0145) * * *$ & $(0.1127)$ \\
\hline Revolution & 0.0155 & --- & --- & --- \\
\hline & $(0.0139)$ & --- & --- & --- \\
\hline Observations & 112 & 453 & 207 & 108 \\
\hline Sargan/Hansen Test & 47.8339 & 32.0371 & 17.8054 & 59.9375 \\
\hline p-value & 0.675 & 0.1919 & 0.2158 & 0.2100 \\
\hline $\mathbf{A R}(\mathbf{1})$ & -3.0639 & -3.5174 & -1.9942 & -3.1480 \\
\hline p-value & 0.0022 & 0.0004 & 0.0461 & 0.0016 \\
\hline $\mathbf{A R}(2)$ & -0.2570 & 1.2324 & -0.3711 & -0.2610 \\
\hline p-value & 0.7972 & 0.2178 & 0.7106 & 0.7941 \\
\hline Wald Test $\left(\chi^{2}\right)$ & 1505.10 & 1582.47 & 4107.55 & 622.82 \\
\hline p-value & 0.0000 & 0.0000 & 0.0000 & 0.0000 \\
\hline
\end{tabular}

Notes: Standard errors are shown below the coefficients. ${ }^{* * *} \mathrm{p}<0.001,{ }^{* *} \mathrm{p}<0.01,{ }^{*} \mathrm{p}<0.05, \dagger \mathrm{p}<0.1$

Table 10. Determinants of capital structure using GMM Estimation (Others)

\begin{tabular}{l|l|l|l|l}
\hline Variable & \multicolumn{1}{c|}{ Egypt } & \multicolumn{1}{c}{ Turkey } & \multicolumn{1}{c}{ Brazil } & \multicolumn{1}{c}{ Argentina } \\
\hline Lagged Book Leverage & $\mathbf{0 . 3 4 3 3}$ & $\mathbf{0 . 6 5 8 1}$ & $\mathbf{0 . 7 6 4 6}$ & $\mathbf{0 . 8 5 9 6}$ \\
& $(0.0321)^{* * *}$ & $(0.0724)^{* * *}$ & $(0.0047)^{* * *}$ & $(0.0770)^{* * *}$ \\
Size & $\mathbf{0 . 0 2 9 4}$ & $\mathbf{0 . 0 2 0 2}$ & $\mathbf{- 0 . 0 2 9 2}$ & $\mathbf{0 . 1 1 1 5}$ \\
Profitability & $(0.0117)^{* *}$ & $(0.0177)$ & $(0.0019)^{* * *}$ & $(0.0432)^{* *}$ \\
Tangibility & $\mathbf{- 0 . 4 8 0 8}$ & $\mathbf{- 0 . 3 8 5 3}$ & $\mathbf{- 0 . 3 7 6 4}$ & $\mathbf{- 0 . 5 5 3 5}$ \\
& $(0.0874)^{* * *}$ & $(0.0925)^{* * *}$ & $(0.0075)^{* * *}$ & $(0.1591)^{* * *}$ \\
Volatility & $\mathbf{- 0 . 0 6 7 8}$ & $\mathbf{- 0 . 3 4 2 3}$ & $\mathbf{0 . 2 0 2 8}$ & $\mathbf{1 . 4 7 8 1}$ \\
& $(0.3120)$ & $(0.1989) \dagger$ & $(0.0176)^{* * *}$ & $(0.8866) \dagger$ \\
GDP & $\mathbf{- 0 . 0 6 7 8}$ & $\mathbf{- 0 . 3 4 2 3}$ & $\mathbf{0 . 2 0 2 8}$ & $\mathbf{1 . 4 7 8 1}$ \\
& $(0.3120)$ & $(0.1989) \dagger$ & $(0.0176)^{* * *}$ & $(0.8866) \dagger$ \\
Inflation & $\mathbf{0 . 0 8 6 6}$ & $\mathbf{1 7 . 7 6 2 0}$ & $\mathbf{1 . 1 4 7 9}$ & $\mathbf{0 . 0 8 4 8}$ \\
& $(0.0926)$ & $(11.5314) \dagger$ & $(0.0385)^{* * *}$ & $(0.0385)^{*}$ \\
Market & $\mathbf{- 0 . 0 7 2 8}$ & $\mathbf{3 5 . 5 0 2 2}$ & $\mathbf{0 . 4 9 6 4}$ & $\mathbf{- 0 . 0 2 2 4}$ \\
& $(0.1426)$ & $(22.7644)$ & $(0.0688)^{* * *}$ & $(0.0155)^{* *}$ \\
Revolution & $\mathbf{0 . 0 3 3 1}$ & $\mathbf{- 5 . 7 5 1 7}$ & $\mathbf{- 0 . 1 0 8 0}$ & $\mathbf{- 0 . 2 3 6 0}$ \\
& $(0.0354)$ & $(3.3488) \dagger$ & $(0.0107)^{* * *}$ & $(0.1430) \dagger$ \\
\hline Observations & 0.0111 & --- & --- & -- \\
Sargan/Hansen Test & $\mathbf{0 . 0 1 6 9 )}$ & $\mathbf{- -}$ & $\mathbf{- -}$ & $\mathbf{- -}$ \\
p-value & 150 & 936 & 690 & 270 \\
AR(1) & 57.2602 & 60.8281 & 61.5392 & 9.0073 \\
p-value & 0.355 & 0.0848 & 0.0756 & 0.1088 \\
AR(2) & -3.9554 & -6.6033 & -2.6522 & -6.3605 \\
p-value & 0.0001 & 0.0000 & 0.0080 & 0.0000 \\
Wald Test $\left(\chi^{2}\right)$ & -1.1842 & 1.2352 & -0.1921 & 1.5607 \\
p-value & 0.2363 & 0.2168 & 0.8476 & 0.1186 \\
\hline
\end{tabular}

Notes: Standard errors are shown below the coefficients. ${ }^{* * *} \mathrm{p}<0.001,{ }^{* *} \mathrm{p}<0.01,{ }^{*} \mathrm{p}<0.05, \dagger \mathrm{p}<0.1$ 
According to outcome in presented tables (6 to 10), first order lag is consistently positive and highly significant for the four countries under study both on aggregate / all sectors level and on economic sector level.

Firm size is significantly positively related to firm's capital structure in Egypt, Turkey, Brazil \& Argentina (table 6). The result verifies trade-off theory. The positive coefficient evidences that larger firms are more diversified hence, have more stability and less volatility in cash flow, which lessens default risk (too-big-to-fail). The implication of results on firm size contradicts expected constant positive sign (firm size - hypothesis $\mathrm{H}_{1}$ ).

Profitability is the only independent variable that is consistently negative and highly significant for all countries under study both on aggregate (as reflected in table 6) all sectors level and on economic sector level (tables 7-10). The only exception is for reduced level of significance in Egypt under consumer non-cyclicals.

Cross-country results on aggregate level (table 6) reflect that profitability is significantly negatively related to firm's capital structure in Egypt, Turkey, Brazil \& Argentina. The result verifies pecking order theory. The negative coefficient evidences that profitable firms can use earnings to fund investment opportunities and hence have less need for external debt. Due to information asymmetry, external funds are more expensive than retained earnings. This validates why more profitable firms prefer internal financing as a cheaper form than external financing. Negative influence of profitability on leverage increases with increase in firm size. This result is consistent with empirical results of Rajan \& Zingale (1995), Booth et al. (2001), Jong (2008). Size of the coefficient is highest for Brazil, followed by Turkey, Argentina and finally Egypt. The implication of results on profitability give supportive evidence to expected constant negative sign (profitability - hypothesis $\mathrm{H}_{2}$ ).

Asset tangibility varies in sign and significance between the 4 countries under study both on aggregate level (all sectors- table 6) and on economic sectors level (tables 7-10). Tangibility variable is generally positive and significant for most of the countries both on aggregate (table 6) and economic sector level (tables 7-10). There are always 3 out of 4 countries under study having positive $\&$ significant coefficient on tangibility. Cross-country results on aggregate level (table 6) reflect that tangibility is significantly positively related to firm's capital structure in Egypt, Turkey \& Brazil. Argentina being the only exception with negative and insignificant coefficient. The positive sign result implies that tangibility tends to be associated with increases in debt ratio which is validated by both trade-off theory and pecking order theory. The positive coefficient evidences that firms with relatively safe, tangible assets have lower asymmetric information risk; along with being privileged that tangible assets can be collateralized. This would allow more borrowing than firms with risky, intangible assets. Agency theory addresses relationship between tangibility and leverage in both directions; positive and negative. Focusing primarily on positive relationship which represents majority of results, as debt helps control agency cost of managerial discretion by preventing managers from spending excess cash flow in unprofitable investments. Hence, our results support trade off theory, pecking order theory and one- fold of agency theory linked to controlling agency cost of managerial discretion. This result is consistent with empirical results of Rajan \& Zingale (1995), Jong (2008), Frank \& Goyal (2009). Worth noting that size of the positive coefficient is highest for Turkey, followed by Egypt and finally Brazil. Argentina size of coefficient is the lowest, negative and insignificant. The implication of results on tangibility contradicts expected constant positive sign (tangibility hypothesis $\mathrm{H}_{3}$ ).

Mixed results on volatility variable regression coefficient was found in 4 countries under study, not only in terms of the sign (positive or negative), but also in terms of significance. Differences across 4 countries occurred both on aggregate (all sectors - table 6) and on economic sectors level (tables 7-10). Cross-country results on aggregate level reflect that volatility is significantly positively related to firm's capital structure in Egypt, Turkey and Brazil. Argentina being the only exception with negative and insignificant coefficient. A negative significant effect of volatility / business risk is generally expected (hypothesis $\mathrm{H}_{4}$ ), but results revealed a positive one. This contradicts many previous studies reflecting negative relationship between leverage and volatility. Explanation for such results can be linked to the financial system orientation of countries under study. Market-based countries follow common negative relationship between volatility and leverage, whereas bank-oriented countries are the complete opposite (Antoniou et al., 2006). Hence, results reveal that countries under study are bank-oriented countries, whereby firms have stronger ties with lenders, this gives bank system better ability to select and approve borrowers compared to market-based countries. Hence, this would make equity more expensive and urge firms to increase borrowing particularly that stronger ties with lenders would reduce actual cost of failure to service debt. Worth noting that size of the positive coefficient is highest for Turkey, followed by Egypt and finally Brazil. Argentina size of coefficient is the lowest, negative and insignificant. The implication of results on volatility contradicts expected negative sign (volatility - hypothesis $\mathrm{H}_{4}$ ). 
Impact of GDP growth is not uniform across the 4 countries neither on aggregate / all sectors level (table 6) nor on economic sectors level (tables 7-10). Mixed results for GDP growth variable regression coefficient applies for the sign, size and significance. Cross-country results on aggregate level, sign for GDP growth is positive for all countries except Egypt. A positive significant effect of GDP growth is generally expected (hypothesis $\mathrm{H}_{5}$ ) while results for Egypt is different. A positive relationship implies that the country has healthier economic conditions and hence, firms are more likely to take more debt. This complies to empirical results by Booth et al. (2001), Jong (2008) and Frank \& Goyal (2009). The negative sign, on the other hand, aligns with pecking order theory, whereby increase in internal funds during expansion lowers need for external financing. In addition, increase in leverage during economic downturn (a negative relationship) supports in resolving agency costs of managerial discretion in compliance to agency theory. Worth noting that size of the positive coefficient 13.42 for Turkey is the highest, followed by Brazil 2.43, Argentina 0.41 \& finally Egypt -0.16. The implication of results on GDP growth contradicts expected positive sign (GDP growth - hypothesis $\mathrm{H}_{5}$ ).

Cross-country results on aggregate level (table 6) reflect that inflation is significantly positively related to firm's capital structure in 4 countries under study. This complies with many previous studies reflecting positive relationship between leverage and expected inflation. Debt issuance tend to increase when interest rate drops and expected inflation is high. Several empirical studies confirm significance of market timing in debt decision (Marsh (1982), Graham \& Harvey (2001), Bancel \& Mitto (2004), Frank \& Goyal (2009)). The implication of results on aggregate level (all sectors) give supportive evidence to expected positive sign (inflation - hypothesis $\mathrm{H}_{6}$ ).

A positive significant effect of stock market development contradicts expected negative sign (hypothesis $\mathrm{H}_{7}$ ). However, results comply to what was referred to by Demirguc-kunt and Maksimovic (1996) as "visual evidence is striking". Impact of stock market development on economies vary in accordance to degree of significance these markets play in addressed economies. For a market like Egypt for example where stock market is at early stages of development, enhancement in information quality and degree of monitoring transactions could be a driving force for lenders to increase debt financing. As such, a positive significant relationship materializes. This would be particularly valid for larger firms which are the ones that are mainly listed in Egyptian stock exchange. Turkey on the other hand, stock market is at a higher degree of significance, as such further stock market development would lead to reduction in debt financing. In addition to a boost in equity financing, as evidenced by significant negative relationship. Sophistication of realizing true driver behind attained results also materializes from the fact that knowing whether country under study is bank oriented or market oriented is important. Rajan and Zingales (1995) presents contradictory argument that bank oriented countries could be in favor of debt financing to allow more control by lenders. On the other hand, decision makers in companies operating in these countries might stop borrowing beyond a certain point. Majority of empirical evidence find a significant negative relationship between leverage and stock market development (Booth et al. (2001); Deesomsak et al. (2004); Frank and Goyal (2009). The implication of results on stock market development contradicts expected consistent negative sign (stock market development - hypothesis $\mathrm{H}_{7}$ ).

\section{Conclusion and Recommendations}

\subsection{Conclusion}

The findings reveal that Egyptian firms on average are not highly leveraged. While this reduce their vulnerability, it raises questions about adequacy of access to credit. A clear declining pattern for Egyptian firm's average of total debt level is not a recent phenomenon and was persistent for the last seven years during period under study, as depicted by graph presented earlier. Low financial leverage in Egypt could not be fully explained by the independent variables dealt with in this study. It appears other factors are relevant in explaining low leverage ratio of Egyptian firms. Some of these factors could be due to supply side of lending institutions and others due to demand side of credit from borrowers.

On the supply side, primary reason for constraints on bank lending is the common preference for banks to extend loans to large corporate clients as they are considered less risky. Small and medium-sized enterprises (SMEs) encounter significant constraints on credit availability / access to finance, despite of accounting for $90 \%$ of all private sector establishments (Krasniqi, 2007, Abdulsaleh and Worthington, 2013). Second reason was clearly Stated by Naceur and Kandil (2013): "factors that affect the willingness or capacity of banks to lend may include liquidity constraints, in response to monetary policy instruments that affect available lendable funds; or collateral requirements; or a shift in lending strategy to improve indicators in response to high nonperforming loans (NPLs); along with macroeconomic indicators". Third reason is shift of Egyptian banks' portfolio towards financing high return \& low risk government debt securities to fund government deficit (12.5\% of GDP in year 2016 - Bloomberg Business Week Magazine August issue 2017) and shrinkage in loan issuance to private sector. 
This was referred to as the "lazy bank model" (Kumhof and Tanner, 2005; Emran and Farazi, 2009); which had an adverse effect on both investment and economic growth.

In addition to local banking practices which influence bank lending behavior, international agreements reached in Basel (I, II \& III) reflects the fourth factor under supply side constraints. Its significance stems from the fact that effect of capital adequacy requirements on credit growth can't be disregarded particularly that high cost of raising capital makes either shifting the composition of assets in bank's portfolio towards less risky assets or decreasing total assets; an unavoidable two options for banks. As such, not only is corporate capital structure a puzzle (Myers, 1984); but also this paper proposes that "credit growth drivers \& constraints" remain a puzzle.

On the demand side, primary reason for constraints on consumer borrowing is that self-financing is prevalent in developing nations like Egypt and can substitute bank loans (Dackwan et al., 2004). SMEs constitute majority of businesses in Egypt. Preference of SMEs for informal financing is driven by internal behavioral factors as exemplified by Tolba, Seoudi and Fahmy (2014) whereby model they developed included, but not limited to the following factors: knowledge of financial products, perception for bank's service quality and previous experience for applying to a loan. National culture is another non-financial factor mentioned by Nomani (2003), whereby conservative cultures place more emphasis on mastery and maintenance of status quo, hence use less debt financing. Religion is another non-financial factor, where many Muslims prefer banking to be online with Shari'a. Finally, in a study conducted by Kotler and Keller (2006), reference groups, family and social status are social factors influencing consumer / client borrowing behavior.

\subsection{Recommendations}

The findings allow corporate managers to take profitability into consideration when making financing decisions. The information that the findings covey regarding profitability as the only variable for the four countries being highly significant with negative coefficient can aid them in reducing their preference of debt financing. This will result in not fully exploiting the tax credits from debt. Policy makers, on the other hand, can encourage profitable firms in investing retained profits along with providing tax incentives resulting in a lower tax burden.

The researchers suggest further studies on capital structure could include: comparison between lending behavior in both large and small firms, decision making process in both types and across countries, role of banks enticing SMEs into credit financing needs and obstacles from both the supply side and the demand side need to be looked at. Also, proposed dilemma "credit growth drivers \& constraints" from bank's perspective in conjunction with Basel risk-based capital adequacy requirements is an interesting unresolved area for future research particularly in the form of comparative analysis between countries at different development levels.

\section{References}

Abdulsaleh, A. M., \& Worthington, A. C. (2013). Small and Medium-Sized Enterprises Financing: A Review of Literature. International Journal of Business and Management, 8(14), 36-54. Business Source Complete. Web. 26 Feb. 2014. https://doi.org/10.5539/ijbm.v8n14p36

Alber, N. (2018). Asset Allocation, Capital Structure, Theory of the Firm and Banking Performance: A Panel Analysis. In Ozatac \& Gökmenoglu K. K. (Eds.), Emerging Trends in Banking and Finance, Springer Proceedings in Business and Economics. https://doi.org/10.1007/978-3-030-01784-2_3

Al-Shubiri, F. N. (2011). Capital structure and market power: evidence from Jordanian banks. Managing Global Transitions, 289-310.

Antoniou, A., Guney, Y., \& Paudyal, K. (2006). The determinants of debt maturity structure: evidence from France, Germany and the UK. European Financial Management, 12(2), 161-194. https://doi.org/10.1111/j.1354-7798.2006.00315.x

Baker, M., \& Wurgler, J. (2002). Market timing and capital structure. The Journal of Finance, 57(1), 1-32. https://doi.org/10.1111/1540-6261.00414

Bancel, F., \& Mittoo, U. R. (2004). Cross-Country Determinants of Capital Structure Choice: A Survey of European Firms. Financial Management, 33(4), 103-132.

Booth, L. et al. (2001). Capital structures in Developing countries. Journal of Finance, 56(1), 87-130. https://doi.org/10.1111/0022-1082.00320

Dackwan, K., Destan, K., \& Cavusgil, S. T. (2004). The role of family conglomerates in emerging markets: What Western companies should know. Thunderbird International Business Review, 46, 13-20. https://doi.org/10.1002/tie.10108 
Deesomsak, R., Paudyal, K., \& Pescetto, G. (2004). The determinants of capital structure: evidence from the Asia Pacific region. Journal of Multinational Financial Management, 14(4), 387-405. https://doi.org/10.1016/j.mulfin.2004.03.001

Demirgüç-Kunt, A., \& Maksimovic, V. (1996). Stock Market Development and Financing Choices of Firms. The World Bank Economic Review, 10(2), 341-369. https://doi.org/10.1093/wber/10.2.341

El-Domiaty, T., \& Mohamed, I. (2008). Modeling capital structure decisions in a transition market: Empirical analysis of firms in Egypt. Review of quantitative Finance \& Accounting, 32(3), 211-233. https://doi.org/10.1007/s11156-008-0091-x

Emran, M. S., \& Farazi, S. (2009). Lazy Banks? Government Borrowing and Private Credit in Developing Countries. Institute for International Economic Policy Working Paper Series No. 2009-9.

Fama, E. F., \& French, K. R. (2002). Testing trade-off and Pecking-order: Predictions about dividends and debt. Review of Financial Studies, 15(1), 1-33. https://doi.org/10.1093/rfs/15.1.1

Faulkender, M. (2005). Hedging or Market Timing? Selecting the Interest Rate Exposure of Corporate Debt. The Journal of Finance, LX(2), 931-962. https://doi.org/10.1111/j.1540-6261.2005.00751.x

Frank, M. Z., \& Goyal, V. K. (2009). Capital structure decisions: which factors are reliably important? Financial Management, 38(1), 1-37. https://doi.org/10.1111/j.1755-053X.2009.01026.x

Friend, I., \& Lang, L. H. P. (1988). An empirical test of the impact of managerial self-interest on corporate capital structure. Journal of Finance, 43, 271-281. https://doi.org/10.1111/j.1540-6261.1988.tb03938.x

Gajurel, D. P. (2005). Determinants of Capital Structure in Nepalese Enterprises (Published Master's Degree Thesis, Kathmandu: Tribhuvan University, Nepal). https://doi.org/10.2139/ssrn.778106

Gaud, P. E., Jani, M. H., \& Bender, A. (2005). The Capital Structure of Swiss Companies: An Empirical Analysis using Dynamic Panel Data. European Financial Management. https://doi.org/10.1111/j.1354-7798.2005.00275.x

Graham, J. R., \& Harvey, C. R. (2001). The theory and practice of corporate financing evidence from the field. Journal of Financial Economics, 60(2), 187-243. https://doi.org/10.1016/S0304-405X(01)00044-7

Harris, M., \& Raviv, A. (1991). The theory of capital structure. Journal of Finance, 46(1), 297-355. https://doi.org/10.1111/j.1540-6261.1991.tb03753.x

Iqbal, A., \& Ortenca, K. (2013). Impact of financial crisis on capital structure of UK firms. Paper submitted in Conference of Multinational Finance, Turkey.

Jensen, M. (1986). Agency cost of free cash flow, corporate finance and takeovers. American Economic Review, 76, 323-329.

Jensen, M., \& Meckling, W. (1976). Theory of the firm: Managerial behaviour, agency costs and capital structure. Journal of Financial Economics, 3(4), 305-306. https://doi.org/10.1016/0304-405X(76)90026-X

Jong, Abe de, R. K., \& Thuy, T. N. (2008). Capital Structure around the World: The Roles of Firm- and Country-Specific Determinants. Journal of Banking \& Finance, 32(9), 1954-1969. https://doi.org/10.1016/j.jbankfin.2007.12.034

Kester, C. W. (1986). Capital and ownership structure: a comparison of United States and Japanese corporations. Financial Management, 15, 5-16. https://doi.org/10.2307/3665273

Korajczyk, R. A., \& Levy, A. (2003). Capital structure choice: Macroeconomic conditions and financial constraints. Journal of Financial Economics. https://doi.org/10.1016/S0304-405X(02)00249-0

Kotler, P., \& Keller, K. L. (2006). Marketing Management (12th ed.). Upper Saddle River, NJ: Pear-son Education.

Krasniqi, B. A. (2007). Barriers to entrepreneurship and SME growth in transition: The Case of Kosova. Journal of Development Entrepreneurship, 12, 71-94. https://doi.org/10.1142/S1084946707000563

Kumhof, M., \& Evan, T. E. (2005). Government Debt: A Key Role in Financial Intermediation. IMF Working Paper 05/57. https://doi.org/10.5089/9781451860764.001

Long, M., \& Maltiz, I. (1985). The investment-financing nexus: some empirical evidence. Midland Corporate Finance Journal, 3, 53-59.

Marsh, P. (1982). The Choice between Equity and Debt: An Empirical Study. Journal of Finance, 37(1), 121-144. https://doi.org/10.1111/j.1540-6261.1982.tb01099.x 
Modigliani, F., \& Miller, M. H. (1958). The cost of capital, corporation finance and the theory of investment. American Economic Review, 48(3), 261-297.

Mostarac, E., \& Suzana, P. (2013). Determinants of capital structure of Croatian enterprises before and during financial crisis. Journal of Economics, 153-162.

Myers, S. C. (1984). The capital structure puzzle. Journal of Finance, 39(3), 574-592. https://doi.org/10.1111/j.1540-6261.1984.tb03646.x

Myers, S. C. (2001). Capital Structure. Journal of Economic Perspectives, 15(2), 81-102. https://doi.org/10.1257/jep.15.2.81

Myers, S. C., \& Majluf, N. (1984). Corporate financing and investment decisions when firms have information that investors do not have. Journal of Financial Economics, 13(2), 187-221. https://doi.org/10.1016/0304-405X(84)90023-0

Naceur, S., \& Kandil, M. (2013). Basel Capital Requirements and Credit Crunch in the MENA Region. IMF Working Paper. https://doi.org/10.5089/9781475586275.001

Nomani, F. (2003). The Problem of Interest and Islamic Banking in a Comparative Perspective: The Case of Egypt, Iran and Pakistan. Review of Middle East Economics and Finance, 1(1), 37-70. https://doi.org/10.1080/1475368032000061644

Rajan, R. G., \& Zingales, L. (1995). What do we know about capital structure? Some evidence from International data. Journal of Finance, 50(5), 1421-1460. https://doi.org/10.1111/j.1540-6261.1995.tb05184.x

Ross, S. (1977). The determination of financial structure: the incentive-signalling approach. The Bell Journal of Economics, 8(1), 23-40. https://doi.org/10.2307/3003485

Titman, S., \& Wessels, R. (1988). The determinants of capital structure choice. Journal of Finance, 43(1), 1-19. https://doi.org/10.1111/j.1540-6261.1988.tb02585.x

Tolba, A., Seoudi, I., \& Fahmy, K. (2014). Factors Influencing Intentions of Egyptian MSME Owners in Taking Commercial Bank Loans. Journal of Small Business \& Entrepreneurship, 27(6), 497-518. https://doi.org/10.1080/08276331.2015.1102478

Wald, J. K. (1999). How firm characteristics affect capital structure: an international comparison. Journal of Financial Research, 22(2), 161-187. https://doi.org/10.1111/j.1475-6803.1999.tb00721.x

Watson, D., \& Head, A. (2010). Corporate Finance: Principles \& Practice. London: Prentice Hall.

Youssef, I. S. (2018). A Model to examine influence of risks on capital structure (PhD dissertation). Ain Shams University, Cairo, Egypt. 


\section{Appendices}

Appendix A. Comparison of descriptive statistics of all variables (Industrials)

\begin{tabular}{|c|c|c|c|c|c|c|c|c|c|}
\hline Country & Statistic & Book Leverage & Size & Profitability & Tangibility & Volatility & GDP & Inflation & Market \\
\hline \multirow{6}{*}{ Egypt } & Obs. & 259 & 262 & 251 & 262 & 262 & 286 & 286 & 260 \\
\hline & Mean & 0.2436 & 11.3367 & 0.0624 & 0.3024 & 0.0714 & 0.164 & 0.0994 & 0.4361 \\
\hline & Median & 0.2213 & 11.2651 & 0.0673 & 0.2659 & 0.048 & 0.1635 & 0.1009 & 0.3072 \\
\hline & SD & 0.1754 & 1.8696 & 0.0923 & 0.2444 & 0.0806 & 0.0415 & 0.0321 & 0.2952 \\
\hline & Min. & 0 & 5.9108 & -0.3041 & 0.0001 & 0.0071 & 0.0876 & 0.0479 & 0.1659 \\
\hline & Max. & 0.6817 & 15.2003 & 0.3856 & 0.769 & 0.5223 & 0.2103 & 0.1831 & 1.0674 \\
\hline \multirow{6}{*}{ Turkey } & Obs. & 763 & 763 & 753 & 764 & 764 & 792 & 792 & 792 \\
\hline & Mean & 0.2735 & 11.9652 & 0.0644 & 0.3774 & 0.0808 & 0.0577 & 0.0829 & 0.2904 \\
\hline & Median & 0.238 & 11.9692 & 0.0559 & 0.3725 & 0.0618 & 0.063 & 0.0857 & 0.2912 \\
\hline & SD & 0.1997 & 1.6384 & 0.0912 & 0.2194 & 0.0802 & 0.0435 & 0.012 & 0.0824 \\
\hline & Min. & 0 & 2.9444 & -0.2108 & 0 & 0.0163 & -0.0597 & 0.0625 & 0.1538 \\
\hline & Max. & 0.7911 & 15.5474 & 0.3888 & 1.4291 & 1.4211 & 0.105 & 0.1045 & 0.4211 \\
\hline \multirow{6}{*}{ Brazil } & Obs. & 977 & 966 & 967 & 959 & 977 & 1001 & 1001 & 1001 \\
\hline & Mean & 0.3416 & 13.8127 & 0.0895 & 0.3807 & 0.1754 & 0.1077 & 0.0581 & 0.5455 \\
\hline & Median & 0.3265 & 13.9925 & 0.0939 & 0.3776 & 0.0617 & 0.1087 & 0.0568 & 0.4979 \\
\hline & SD & 0.1759 & 1.9457 & 0.1201 & 0.2445 & 1.29 & 0.0333 & 0.014 & 0.2064 \\
\hline & Min. & 0 & 4.7274 & -1.4929 & 0 & 0.0127 & 0.0383 & 0.0364 & 0.272 \\
\hline & Max. & 1.3474 & 17.9406 & 0.6606 & 0.9466 & 29.3995 & 0.1659 & 0.0903 & 0.9804 \\
\hline \multirow{6}{*}{ Argentina } & Obs. & 415 & 415 & 410 & 415 & 415 & 429 & 429 & 429 \\
\hline & Mean & 0.2411 & 12.6036 & 0.0678 & 0.6229 & 0.0857 & 0.2562 & 1.58 & 0.1371 \\
\hline & Median & 0.2264 & 12.5666 & 0.0589 & 0.7149 & 0.0796 & 0.2693 & 1.78 & 0.1143 \\
\hline & SD & 0.1663 & 1.0504 & 0.1032 & 0.2337 & 0.0448 & 0.0724 & 0.591 & 0.0561 \\
\hline & Min. & 0 & 10.103 & -0.1439 & 0.0062 & 0.0227 & 0.0855 & 0.68 & 0.0627 \\
\hline & Max. & 0.7668 & 14.9579 & 0.3635 & 0.922 & 0.3953 & 0.3676 & 2.73 & 0.2395 \\
\hline
\end{tabular}

Appendix B. Comparison of descriptive statistics of all variables (Consumer Non-Cyclicals)

\begin{tabular}{llcccccccc}
\hline Country & Statistic & Book Leverage & Size & Profitability & Tangibility & Volatility & GDP & Inflation & Market \\
\hline \multirow{5}{*}{ Egypt } & Obs. & 185 & 185 & 182 & 185 & 185 & 198 & 198 & 180 \\
& Mean & 0.1956 & 11.1753 & 0.0745 & 0.4148 & 0.0655 & 0.164 & 0.0994 & 0.4361 \\
& Median & 0.1614 & 11.0292 & 0.0744 & 0.4143 & 0.0452 & 0.1635 & 0.1009 & 0.3072 \\
& SD & 0.1597 & 1.1612 & 0.0953 & 0.181 & 0.0696 & 0.0415 & 0.0322 & 0.2954 \\
& Min. & 0 & 8.2868 & -0.3043 & 0.0279 & 0.0194 & 0.0876 & 0.0479 & 0.1659 \\
& Max. & 0.9276 & 13.7438 & 0.484 & 0.809 & 0.5006 & 0.2103 & 0.1831 & 1.0674 \\
\hline \multirow{6}{*}{ Turkey } & Obs. & 627 & 623 & 611 & 627 & 627 & 649 & 649 & 649 \\
& Mean & 0.3755 & 11.6435 & 0.041 & 0.3811 & 0.1458 & 0.0577 & 0.0829 & 0.2904 \\
& Median & 0.2724 & 11.8238 & 0.0446 & 0.3636 & 0.0737 & 0.063 & 0.0857 & 0.2912 \\
& SD & 0.7665 & 1.7498 & 0.3753 & 0.2083 & 0.2647 & 0.0435 & 0.012 & 0.0824 \\
& Min. & 0 & 3.2189 & -3.4012 & 0.0003 & 0.0121 & -0.0597 & 0.0625 & 0.1538 \\
& Max. & 10.7343 & 15.4427 & 7.9242 & 0.9821 & 2.6703 & 0.105 & 0.1045 & 0.4211 \\
\hline \multirow{5}{*}{ Brazil } & Obs. & 457 & 455 & 456 & 457 & 457 & 462 & 462 & 462 \\
& Mean & 0.2847 & 13.3973 & 0.0957 & 0.3093 & 0.2068 & 0.1077 & 0.0581 & 0.5455 \\
& Median & 0.2644 & 13.4233 & 0.085 & 0.3056 & 0.0695 & 0.1087 & 0.0568 & 0.4979 \\
& SD & 0.1994 & 1.7502 & 0.1286 & 0.1677 & 1.6629 & 0.0333 & 0.014 & 0.2065 \\
& Min. & 0 & 5.7526 & -0.9763 & 0 & 0.0137 & 0.0383 & 0.0364 & 0.272 \\
& Max. & 1.3535 & 17.7484 & 0.5516 & 0.8467 & 35.4208 & 0.1659 & 0.0903 & 0.9804 \\
\hline & Obs. & 251 & 247 & 248 & 251 & 251 & 264 & 264 & 264 \\
& Mean & 0.2477 & 11.7436 & 0.1123 & 0.3591 & 0.127 & 0.2562 & 1.58 & 0.1371 \\
Argentina & Median & 0.2113 & 11.7005 & 0.1141 & 0.3367 & 0.0778 & 0.2693 & 1.78 & 0.1143 \\
& SD & 0.1925 & 2.1772 & 0.0959 & 0.1897 & 0.113 & 0.0724 & 0.5915 & 0.0561 \\
& Min. & 0 & 1.9459 & -0.1577 & 0.0568 & 0.0228 & 0.0855 & 0.68 & 0.0627 \\
& Max. & 1.0211 & 15.205 & 0.435 & 0.8348 & 0.5137 & 0.3676 & 2.73 & 0.2395 \\
\hline
\end{tabular}


Appendix C. Comparison of descriptive statistics of all variables (Basic Materials)

\begin{tabular}{|c|c|c|c|c|c|c|c|c|c|}
\hline Country & Statistic & Book Leverage & Size & Profitability & Tangibility & Volatility & GDP & Inflation & Market \\
\hline \multirow{6}{*}{ Egypt } & Obs. & 141 & 143 & 139 & 141 & 141 & 143 & 143 & 130 \\
\hline & Mean & 0.2278 & 11.2297 & 0.1274 & 0.3572 & 0.0852 & 0.164 & 0.0994 & 0.4361 \\
\hline & Median & 0.1808 & 11.1965 & 0.12 & 0.3908 & 0.0507 & 0.1635 & 0.1009 & 0.3072 \\
\hline & SD & 0.194 & 1.0297 & 0.0838 & 0.2035 & 0.0948 & 0.0415 & 0.0322 & 0.2958 \\
\hline & Min. & 0 & 8.1948 & -0.1711 & 0.0008 & 0.0146 & 0.0876 & 0.0479 & 0.1659 \\
\hline & Max. & 0.787 & 13.9308 & 0.407 & 0.8022 & 0.5841 & 0.2103 & 0.1831 & 1.0674 \\
\hline \multirow{6}{*}{ Turkey } & Obs. & 506 & 506 & 500 & 506 & 506 & 506 & 506 & 506 \\
\hline & Mean & 0.1441 & 12.1531 & 0.1099 & 0.4262 & 0.0818 & 0.0577 & 0.0829 & 0.2904 \\
\hline & Median & 0.1083 & 12.0661 & 0.0947 & 0.4263 & 0.0667 & 0.063 & 0.0857 & 0.2912 \\
\hline & SD & 0.1335 & 1.0922 & 0.1032 & 0.1337 & 0.0736 & 0.0435 & 0.012 & 0.0824 \\
\hline & Min. & 0 & 9.7561 & -0.2293 & 0.1109 & 0.0134 & -0.0597 & 0.0625 & 0.1538 \\
\hline & Max. & 0.7954 & 15.8041 & 0.3999 & 0.7703 & 1.0765 & 0.105 & 0.1045 & 0.4211 \\
\hline \multirow{6}{*}{ Brazil } & Obs. & 234 & 235 & 233 & 234 & 234 & 242 & 242 & 242 \\
\hline & Mean & 0.2849 & 12.0868 & 0.0675 & 0.3888 & 0.1279 & 0.1077 & 0.0581 & 0.5455 \\
\hline & Median & 0.283 & 12.3735 & 0.081 & 0.3923 & 0.0819 & 0.1087 & 0.0568 & 0.4979 \\
\hline & SD & 0.1954 & 2.1961 & 0.1063 & 0.2698 & 0.134 & 0.0333 & 0.014 & 0.2067 \\
\hline & Min. & 0 & 6.6333 & -0.3798 & 0.0001 & 0.0122 & 0.0383 & 0.0364 & 0.272 \\
\hline & Max. & 1.1626 & 16.8475 & 0.5046 & 0.9036 & 0.9642 & 0.1659 & 0.0903 & 0.9804 \\
\hline \multirow{6}{*}{ Argentina } & Obs. & 119 & 119 & 119 & 119 & 119 & 121 & 121 & 121 \\
\hline & Mean & 0.1844 & 11.6443 & 0.0716 & 0.412 & 0.0728 & 0.2562 & 1.58 & 0.1371 \\
\hline & Median & 0.1244 & 11.5974 & 0.0679 & 0.4961 & 0.0535 & 0.2693 & 1.78 & 0.1143 \\
\hline & SD & 0.1591 & 0.9917 & 0.0848 & 0.2733 & 0.0424 & 0.0726 & 0.5928 & 0.0563 \\
\hline & Min. & 0 & 9.6873 & -0.2895 & 0.0101 & 0.0262 & 0.0855 & 0.68 & 0.0627 \\
\hline & Max. & 0.5945 & 13.6836 & 0.2749 & 0.8855 & 0.2109 & 0.3676 & 2.73 & 0.2395 \\
\hline
\end{tabular}

Appendix D. Comparison of descriptive statistics of all variables (Others)

\begin{tabular}{|c|c|c|c|c|c|c|c|c|c|}
\hline Country & Statistic & Book Leverage & Size & Profitability & Tangibility & Volatility & GDP & Inflation & Market \\
\hline \multirow{6}{*}{ Egypt } & Obs. & 191 & 192 & 187 & 191 & 191 & 198 & 198 & 180 \\
\hline & Mean & 0.2468 & 11.8908 & 0.099 & 0.4651 & 0.0512 & 0.164 & 0.0994 & 0.4361 \\
\hline & Median & 0.2274 & 12.5124 & 0.0907 & 0.4402 & 0.0389 & 0.1635 & 0.1009 & 0.3072 \\
\hline & SD & 0.1657 & 2.1483 & 0.0833 & 0.2018 & 0.0408 & 0.0415 & 0.0322 & 0.2954 \\
\hline & Min. & 0 & 7.2306 & -0.1958 & 0.0928 & 0.0107 & 0.0876 & 0.0479 & 0.1659 \\
\hline & Max. & 0.7918 & 15.4847 & 0.381 & 0.8962 & 0.2893 & 0.2103 & 0.1831 & 1.0674 \\
\hline \multirow{6}{*}{ Turkey } & Obs. & 1074 & 1074 & 1060 & 1075 & 1076 & 1111 & 1111 & 1111 \\
\hline & Mean & 0.2449 & 12.3634 & 0.0743 & 0.3183 & 0.1248 & 0.0577 & 0.0829 & 0.2904 \\
\hline & Median & 0.2039 & 12.1451 & 0.061 & 0.2608 & 0.0655 & 0.063 & 0.0857 & 0.2912 \\
\hline & SD & 0.217 & 2.4334 & 0.1585 & 0.2709 & 0.1926 & 0.0435 & 0.012 & 0.0824 \\
\hline & Min. & 0 & 4.4188 & -1.1829 & 0 & 0.0082 & -0.0597 & 0.0625 & 0.1538 \\
\hline & Max. & 1.5941 & 17.6863 & 0.5947 & 1.3316 & 1.6269 & 0.105 & 0.1045 & 0.4211 \\
\hline \multirow{6}{*}{ Brazil } & Obs. & 783 & 779 & 775 & 781 & 783 & 803 & 803 & 803 \\
\hline & Mean & 0.3637 & 12.8342 & 0.0607 & 0.249 & 6.4625 & 0.1077 & 0.0581 & 0.5455 \\
\hline & Median & 0.296 & 12.7888 & 0.0785 & 0.2029 & 0.0843 & 0.1087 & 0.0568 & 0.4979 \\
\hline & SD & 0.4074 & 1.719 & 0.1754 & 0.2038 & 142.9044 & 0.0333 & 0.014 & 0.2064 \\
\hline & Min. & 0 & 3.5553 & -2.3876 & 0 & 0.0127 & 0.0383 & 0.0364 & 0.272 \\
\hline & Max. & 4.0423 & 16.7492 & 0.6432 & 0.9233 & 3859.311 & 0.1659 & 0.0903 & 0.9804 \\
\hline \multirow{6}{*}{ Argentina } & Obs. & 304 & 304 & 303 & 304 & 304 & 319 & 319 & 319 \\
\hline & Mean & 0.261 & 12.8977 & 0.1236 & 0.454 & 0.075 & 0.2562 & 1.58 & 0.1371 \\
\hline & Median & 0.2588 & 12.9143 & 0.1194 & 0.4872 & 0.067 & 0.2693 & 1.78 & 0.1143 \\
\hline & SD & 0.1728 & 1.7017 & 0.0894 & 0.2406 & 0.0433 & 0.0724 & 0.5913 & 0.0561 \\
\hline & Min. & 0 & 8.9076 & -0.1739 & 0.0474 & 0.0133 & 0.0855 & 0.68 & 0.0627 \\
\hline & Max. & 0.7703 & 15.4967 & 0.3531 & 0.8817 & 0.3234 & 0.3676 & 2.73 & 0.2395 \\
\hline
\end{tabular}

\section{Copyrights}

Copyright for this article is retained by the author(s), with first publication rights granted to the journal.

This is an open-access article distributed under the terms and conditions of the Creative Commons Attribution license (http://creativecommons.org/licenses/by/4.0/). 